\title{
On the nutritional and therapeutic effects of ketone body D- $\beta$-hydroxybutyrate
}

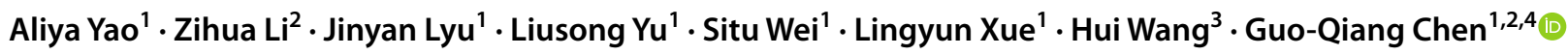

Received: 12 May 2021 / Revised: 26 July 2021 / Accepted: 27 July 2021 / Published online: 20 August 2021

(c) The Author(s), under exclusive licence to Springer-Verlag GmbH Germany, part of Springer Nature 2021

\begin{abstract}
D- $\beta$-hydroxybutyrate (D-3HB), a monomer of microbial polyhydroxybutyrate (PHB), is also a natural ketone body produced during carbohydrate deprivation to provide energy to the body cells, heart, and brain. In recent years, increasing evidence demonstrates that $\mathrm{D}-3 \mathrm{HB}$ can induce pleiotropic effects on the human body which are highly beneficial for improving physical and metabolic health. Conventional ketogenic diet (KD) or exogenous ketone salts (KS) and esters (KE) have been used to increase serum D-3HB level. However, strict adaptation to the KD was often associated with poor patient compliance, while the ingestion of KS caused gastrointestinal distresses due to excessive consumption of minerals. As for ingestion of $\mathrm{KE}$, subsequent degradation is required before releasing D-3HB for absorption, making these methods somewhat inferior. This review provides novel insights into a biologically synthesized D-3HB (D-3-hydroxybutyric acid) which can induce a faster increase in plasma D-3HB compared to the use of KD, KS, or KE. It also emphasizes on the most recent applications of D-3HB in different fields, including its use in improving exercise performance and in treating metabolic or age-related diseases. Ketones may become a fourth micro-nutrient that is necessary to the human body along with carbohydrates, proteins, and fats. Indeed, D-3HB being a small molecule with multiple signaling pathways within the body exhibits paramount importance in mitigating metabolic and age-related diseases. Nevertheless, specific dose-response relationships and safety margins of using D-3HB remain to be elucidated with more research.
\end{abstract}

\section{Key points}

- D-3HB induces pleiotropic effects on physical and metabolic health.

- Exogenous ketone supplements are more effective than ketogenic diet.

- $D-3 H B$ as a ketone supplement has long-term healthy impact.

Keywords PHB $\cdot$ D- $\beta$-hydroxybutyrate $\cdot$ D-3HB $\cdot$ Physical health $\cdot$ Metabolic health $\cdot$ Age-related disease $\cdot$ Ketone body $\cdot$ Micronutrient

Guo-Qiang Chen

chengq@mail.tsinghua.edu.cn

1 MedPHA Bioscience Co. Ltd., Traditional Chinese Medicine Science and Technology Industrial Park of CoOperation Between Guangdong and Macau, Building No.103, 36 Doukou Rd, Hengqin District, Zhuhai 519030, Guangdong Province, China

2 School of Pharmaceutical Sciences, Tsinghua University, Beijing 100084, China

3 Department of Colorectal Surgery, Guangdong Province Biomedical Material Conversion and Evaluation Engineering Technology Center, Institute of Biomedical Innovation, The Sixth Affiliated Hospital of Sun Yat-Sen University, Guangzhou 510655, Guangdong Province, China

4 School of Life Sciences and Dept Chemical Engineering, Center for Synthetic and Systems Biology (CSSB), Tsinghua University, Beijing 100084, China

\section{Introduction}

Energy metabolism in mammalian organisms is typically dependent on carbohydrate digestion which generates adenosine triphosphate (ATP) via glucose metabolism. However, the presence of high glucose had long been implicated in causing detrimental effects that negatively affect human metabolic health such as obesity, Type II Diabetes (T2D), chronic cardiovascular disease (CVDs), and the metabolic syndrome (Horwich and Fonarow 2011). At the same time, glucose hypometabolism also triggers neurodegeneration (Lee and Yau 2020). Intermittent fasting (IF) (Wilkinson et al. 2020) and the ketogenic diet (KD) (Kumar et al. 2021) have been explored as potential non-pharmaceutical interventions to overcome these complications. Mechanistically, 
both IF and KD cause a metabolic switch from glycolysis to ketosis by producing natural ketone bodies in the liver, namely, D- $\beta$-hydroxybutyrate (D-3HB), acetoacetate, and acetone, of which D-3HB accounts for more than $70 \%$ of total ketones produced (Balasse and Féry 1989).

\section{Occurrence and functions of $\mathrm{D}-3 \mathrm{HB}$}

D-3HB is the most prominent ketone body that is naturally produced by the liver during times of carbohydrate deprivation (Cahill 2006). As demonstrated by its chemical structure (Fig. 1), D-3HB is a small molecule with a molecular weight of $104.1 \mathrm{~g} / \mathrm{mol}$ (Fig. 1A) which can easily pass through the bloo D-brain barrier and thin capillary cell walls to supply energy to the brain and muscle
Fig. 1 Chemical structures of D-3HB acid (A) and different forms of ketone supplements (B-E) including ketone salts and esters. (R)-3-hydroxybutyly (R)-3-hydroxybutyrate is synthesized via a transesterification reaction between 1,3-butanediol and ethyl-3-hydroxybutyrate. Bis-hexanoyl (R)-1,3-butanediol is a newly-synthesized ketone ester which can be hydrolyzed into hexanoic acid and 1,3-butanediol. E shows a ketone diester derived from acetoacetate. All structures are redrawn using ChemDraw Professional as original artworks
A) D-3-Hydroxybutyric Acid (D-3HB)<smiles>C[C@@H](O)CC(=O)O</smiles>

B) Sodium D-3-Hydroxybutyrate<smiles>C[C@@H](O)CC(=O)[O-]</smiles>

C) (R)-3-hydroxybutyl ( $R$ )-3-hydroxybutyrate (Ketone Monoester)<smiles>C[C@H](O)CC(=O)OCC[C@@H](C)O</smiles>

D) Bis-Hexanoyl (R)-1,3-butanediol (A Novel Ketogenic Ester Derived from Hexanoic Acid \& 1,3-Butanediol)<smiles>CCCCCC(=O)OCC[C@H](C)OC(=O)CCCCC</smiles>

E) R,S-Butanediol Diacetoacetate (A Ketone Diester Derived from Acetoacetate)<smiles>CC(=O)CC(=O)OCCC(C)OC(=O)CC(C)=O</smiles> 
cells, respectively. During starvation, the body is heavily dependent on ketone bodies as energy fuel whereby two-fifth of fatty acid metabolism in the whole body occurs via hepatic ketogenesis, producing 140-280 g of ketones per day. Individuals undergoing extreme fasting for 4-5 days or longer can exhibit D-3HB levels of up to 4-7 mM (Veech et al. 2001), which is well within the normal physiological range of serum D-3HB in humans (Rich 1990). Over the recent years, there has been a vast number of studies detailing how D-3HB benefits the human body such as enhancing exercise performance (Margolis and O'Fallon 2019), optimizing body composition (Kang et al. 2020), improving metabolic health (Fischer et al. 2019b; Bleeker et al. 2020), and for potential anti-aging treatments (Park and Kim 2020; Habieb et al. 2021).

\section{Exogenous D-3HB supplementations are more effective than the KD}

There has been a rise in demand for the use of exogenous ketone supplements to induce ketosis for improving physical and metabolic health (Poff et al. 2020). Exogenous D$3 \mathrm{HB}$ supplements can be present in the form of ketogenic salt (KS), ketogenic ester (KE), or free acid. The chemical structures of the currently available forms of ketone supplements are available in several forms (Fig. 1B-E). To date, synthetic KS is the most prominent form of ketone supplement which can increase serum D-3HB to approximately $1.2 \mathrm{mM}$ in adults with a small reduction in respiratory exchange ratio (RER) and consequently, increased fatty acid oxidation (O'Malley et al. 2017). However, positive results in terms of enhancing high-intensity exercise performance using KS were only reported in one study when the composition was composed of KS with caffeine, L-taurine, and L-leucine (Kackley et al. 2020).

On the other hand, KE supplements are a superior form of ketone supplement compared to KS due to faster onset and higher bioavailability (Stubbs et al. 2017). The first pure commercially-available KE (i.e., $(R)$-3-hydroxybutyl-(R)-3-hydroxybutyrate monoester, KME) was developed via an enantioselective transesterification reaction catalyzed by the immobilized Candida antarctica lipase B (USA FDA 2015). The KME exhibits a high enantiomeric purity of the D-isomer, which is the natural form present in the body, and produces a rapid effect at elevating serum D-3HB leading to enhanced exercise performance (Cox et al. 2016). More recently, a group at the Buck Institute in the United States synthesized a novel ketone diester which also increases serum D-3HB while stimulating hepatic ketogenesis (Stubbs et al. 2021).

\section{Disadvantages of existing KS and KE}

KS supplements are usually composed of mixed D- and L-isomers, whereby L-3HB is not naturally produced by the body, and its presence in non-racemic $\mathrm{D} / \mathrm{L}-3 \mathrm{HB}$ tends to delay the onset of ketosis (Millet 2019). Another drawback of KS is the increased likelihood of excessive salt consumption which can cause fatal effects such as salt-induced hypertension (Strazzullo et al. 2009). Additionally, in one study where a sodium/calcium D/L-3HB salt was used for treating multi acyl-CoA dehydrogenase deficiency (MADD), the patient reported severe gastrointestinal (GI) side effects which was likely to be due to excessive mineral consumption (Fischer et al. 2018). With respect to the KME, the major downside is that the ester needs to be hydrolyzed in the liver before releasing $\mathrm{D}-3 \mathrm{HB}$, hence, may cause a slight delay in onset compared to the direct absorption of free D-3HB acid (Stubbs et al. 2017). Nevertheless, pure D-3HB acid is currently only available from Sigma-Aldrich as standard samples at a great expense.

It is proposed here a novel pure D-3HB supplement in the free acid form to be manufactured via biosynthesis (Lyu et al. 2021). Next, we have summarized the most recent applications of D-3HB, starting with its utilization in exercise (Margolis and O'Fallon 2019), obesity, and related metabolic complications (Kumar et al. 2021), as well as in major age-related pathologies (Han et al. 2020) that affects human health (Tables 1 and 2). Due to the novelty of having such free acid D-3HB in large amounts, subsequent investigations to establish the pharmacokinetic profiles, safety, and tolerability data in humans, as well as dose-response studies correlated to different medical conditions (Fig. 4), are potential areas that can be studied in future. Further mechanistic research using the free acid may aid in the development of novel therapies for treating metabolic and age-related diseases.

\section{A free $D-3 H B$ acid derived from microbial polyhydroxybutyrate}

To date, the majority of patented methods related to the production of D-3HB were through chemical synthesis (Haas et al. 2018). On the other hand, biological synthesis allows for better enantiomeric control which is selective for the D-isomer and barely introduce heavy metals during the manufacturing process (Chen et al. 2002). In recent years, biosynthesis of the biodegradable polyhydroxyalkanoates (PHA) from microorganisms has raised great attention due to economic and environmental reasons (Anjum et al. 2016). Polyhydroxybutyrate (PHB), being the first identified biodegradable PHA, was composed of D-3HB monomers. Previous research had already shown that PHB could be efficiently produced through bacterial synthesis using a 


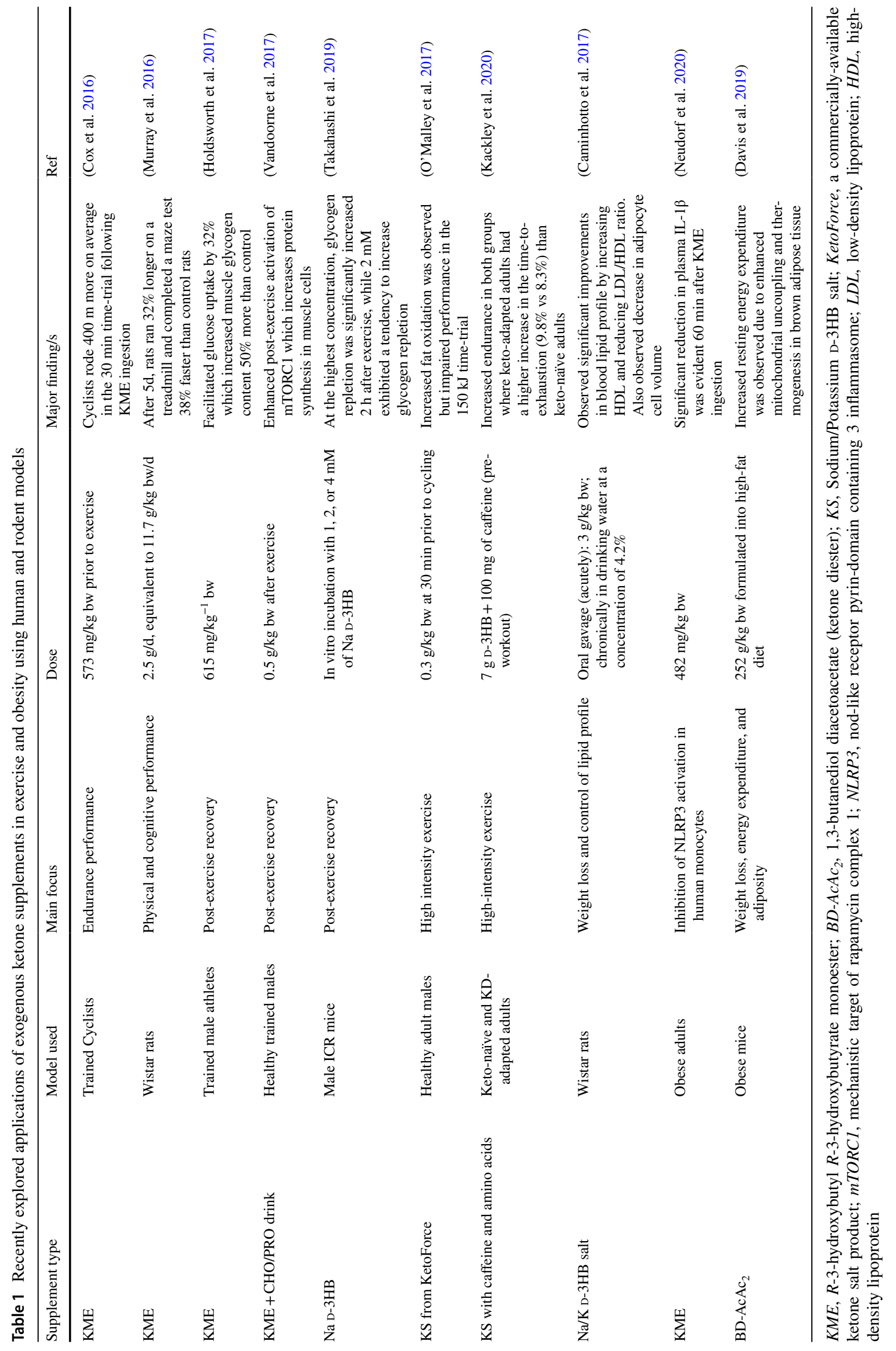


Table 2 Most recently explored medical indications for treatment using D-3HB

\begin{tabular}{|c|c|c|c|c|}
\hline No & Indications & D-3HB effect & Specific mechanism & Ref \\
\hline $1 \mathrm{a}$ & ALZ, PARK, SCZ, HFrEF & Alternative energy fuel & $\begin{array}{l}\text { Restore energy deficits caused by } \\
\text { glucose hypometabolism }\end{array}$ & $\begin{array}{l}\text { (Kashiwaya et al. 2000; Kraeuter et al. } \\
\text { 2020; Yurista et al. 2021b; Monzo } \\
\text { et al. 2021) }\end{array}$ \\
\hline $1 b$ & MADD, FAO diseases & & Replenish acetyl-CoA & $\begin{array}{l}\text { (Fischer et al. 2018, 2019a; Bleeker } \\
\text { et al. 2020) }\end{array}$ \\
\hline 2 & Age-induced sarcopenia & Anti-oxidant & $\begin{array}{l}\text { Reduce reactive oxidative species and } \\
\text { oxidative stress }\end{array}$ & (Wallace et al. 2021) \\
\hline $3 \mathrm{a}$ & $\begin{array}{l}\text { Atherosclerosis } \\
\text { PTSD, anxiety, gout pain, HFpEF }\end{array}$ & Anti-inflammatory & NLRP3 inhibition & $\begin{array}{l}\text { (Goldberg et al. 2017; Yamanashi et al. } \\
\text { 2020; Deng et al. 2021; Zhang et al. } \\
\text { 2021) }\end{array}$ \\
\hline $3 b$ & CKD & & mTORC1 inhibition & (Tomita et al. 2020) \\
\hline $4 a$ & Wound healing, Diabetic foot & Promotes growth and & $\mathrm{hKCs}$ & (Ji et al. 2008; Kesl 2016) \\
\hline $4 b$ & Anti-osteoporosis & proliferation of cells & Osteoblast cells & (Cao et al. 2014) \\
\hline $4 \mathrm{c}$ & Hair loss & & Hair follicular cells & (Han et al. 2007) \\
\hline 5 & $\begin{array}{l}\text { Glioblastomas } \\
\text { Other types of cancer? } \\
\text { Gliomas/melanomas }\end{array}$ & Anti-cancer & $\begin{array}{l}\text { Inhibits glycolytic pathways } \\
\text { Potentiates effect of existing drugs/ } \\
\text { chemotherapy } \\
\text { NLRP3 inhibition }\end{array}$ & $\begin{array}{l}\text { (Maurer et al. 2011; Vallejo et al. 2020) } \\
\text { (Feng et al. 2019; Iyikesici 2020) } \\
\text { (Shang et al. 2018; Tengesdal et al. } \\
\text { 2021) }\end{array}$ \\
\hline 6 & $\begin{array}{l}\text { Influenza A virus } \\
\text { SARS-CoV-2 virus }\end{array}$ & Anti-viral & $\begin{array}{l}\text { Activate } \gamma \delta \text {-T cells to enhance } \\
\text { immune system function }\end{array}$ & (Stubbs et al. 2020) \\
\hline $7 \mathrm{a}$ & Diabetic vascular injury & Kbhb & Н3К9 & (Wu et al. 2020a) \\
\hline $7 \mathrm{~b}$ & Novel anti-cancer therapy? & Kbhb & H3К9, H3К14 & (Dąbek et al. 2020) \\
\hline
\end{tabular}

$A L Z$, Alzheimer's; PARK, Parkinson's; $S C Z$, Schizophrenia; $H F r E F$, heart failure with reduced ejection fraction; $H F p E F$, heart failure with preserved ejection fraction; $M A D D$, multiple acyl-CoA dehydrogenase deficiency; $F A O$, fatty acid oxidation disorders; $P T S D$, post-traumatic stress disorder; $C K D$, chronic kidney disease; mTORC1, mechanistic target of rapamycin complex 1; NLRP3, nod-like receptor pyrin-domain containing 3 inflammasome; $h K C$, human keratinocytes; $K b h b$, lysine- $\beta$-hydroxybutyrylation; $H 3 K 9 / H 3 K 14$, $\beta$-hydroxybutyrylation on lysine residues at position 9 and 14 of histone 3

new strain of bacteria known as Halomonas TD01 (Tan et al. 2011). For the first time, a pure free acid form of D-3HB has been successfully made from biologically synthesized PHB on a kilogram scale via a series of hydrolytic reactions (Lyu et al. 2021). Details on the exact manufacturing process are proprietary. The D-3HB acid was further formulated into a novel supplement for direct consumption which may elicit a more rapid response in terms of elevating blood D-3HB compared to existing KS and KE supplements (Schroeder and Hynes 2021). A simple comparison between chemically synthesized ketone supplements and the free D-3HB acid is provided (Fig. 2).

\section{Applications of D-3HB across different fields}

D-3HB is a small endogenous molecule that acts as both an alternative energy fuel and an intracellular signaling molecule in the body with a myriad number of downstream targets within different tissues and organs, especially the heart and kidneys (Cuenoud et al. 2020). The downstream pathways of D-3HB metabolism could be as either an energy fuel in the mitochondria or a signaling molecule in other extrahepatic cells and tissues (Fig. 3). Thus, D-3HB have been extensively explored in different fields over the past few years in relation to physical and metabolic health (Møller 2020). Interestingly, it has been proposed that D-3HB may provide protection against cardiometabolic complications in high-stress workers due to its ability to mitigate oxidative stress and inflammation (Waldman and McAllister 2020).

Newman and Verdin have extensively reviewed how D$3 \mathrm{HB}$ was regulated and its role as an endogenous histone deacetylase (HDAC) inhibitor within the body, which was significant in modulating metabolism and diseases of aging (Newman and Verdin 2014). Here we have summarized the recent applications of D-3HB in exercise and obesity (Table 1), as well as, the most recently investigated metabolic and age-related conditions using D-3HB (Table 2). An overall summary of the different mechanisms of D-3HB is provided with corresponding medical indications (Fig. 4).

\section{D-3HB and exercise: endurance training and post-exercise recovery}

Nowadays, the use of ketone supplements in exercise is highly popular among athletes for improving endurance performance or enhancing post-exercise recovery to prevent overtraining (Table 1). The use of exogenous ketone 
Fig. 2 Conventional chemically synthesized ketone supplements versus novel biologically synthesized D-3HB acid. Drawbacks of chemically synthesized ketone supplements and key features of the novel D-3HB acid produced through biosynthesis. Image of Halomonas TD01 taken from (Tan et al. 2011). Chemical structures are redrawn using ChemDraw Professional. All other images are produced as original artworks

\section{Chemical Synthesized D-3HB (Salts/Esters)}

Mixed D/L-3HB

Gastrointestinal

Distress

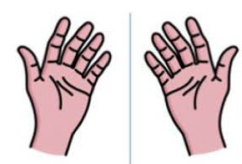

Requires further digestion in

liver (i.e. ketone monoester)
Difficulty \& high expenses in eliminating heavy metals

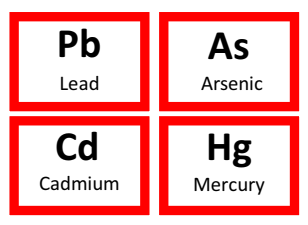

Likely to exceed recommended daily consumption of salts
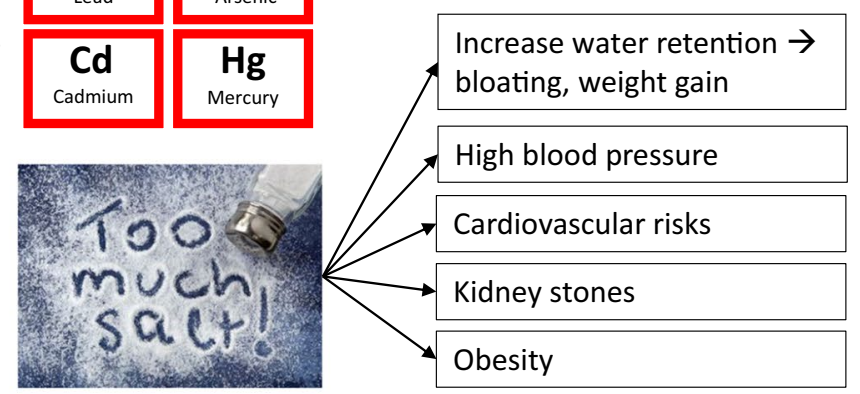

\section{Novel Biologically Synthesized D-3HB Acid}

Raw ingredient derived from bacterium Halomonas TD01

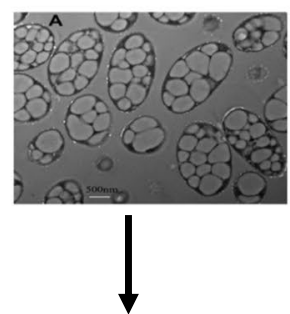

Poly(3-hydroxybutyrate) (PHB)<smiles>CC(C)OC(C)CC(=O)C(C)(C)O</smiles>

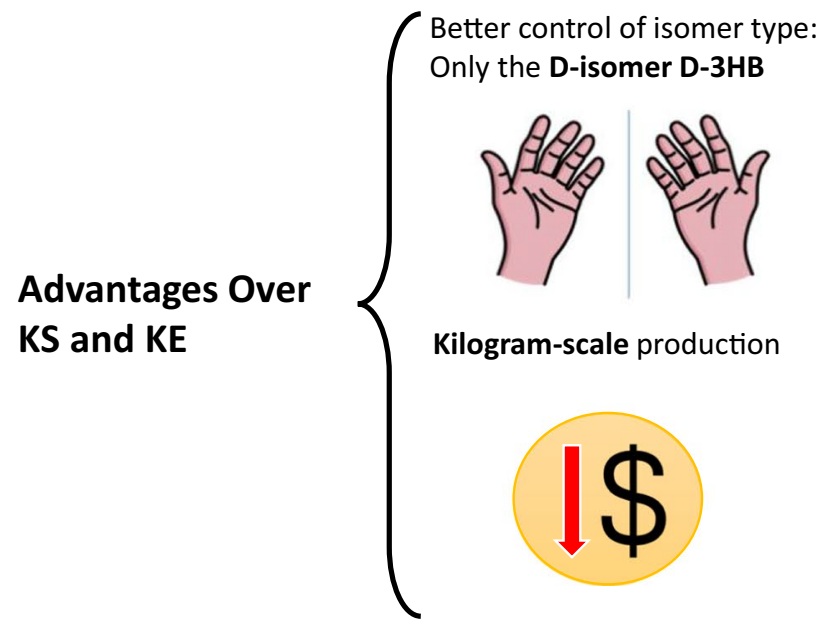<smiles>C[C@@H](O)CC(=O)O</smiles>

3-hydroxybutyrate

Identical to the endogenous $\mathrm{D}-3 \mathrm{HB}$

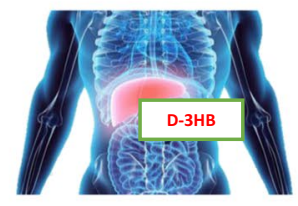

Heavy metal content within ppb level

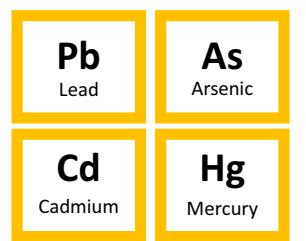


Fig. 3 Mechanism of actions of D-3HB in the mitochondria and downstream signaling pathways on the cellular level. D-3HB serves as (A) an alternative energy fuel by replenishing acetyl-CoA via an independent pathway irrespective of glucose, or (B) an endogenous signaling molecule with functions on HDAC,

NLRP3 inflammasome, and $\mathrm{G}_{\mathrm{i} / \mathrm{o}}$-protein-coupled receptors (i.e., FFAR3 and GPR109A), which lead to a range of downstream effects including inhibition of inflammation and lipolysis, reducing oxidative stress, alleviating atherosclerosis and epigenetic changes (e.g., lysine $\beta$-hydroxybutyrylation on histones which regulate genes in the starvation-responsive metabolic pathway). Abbreviations in figure: PDC, pyruvate dehydrogenase complex; AcAc, acetoacetate; HDACs, histone deacetylases; NLRP3, nod-like receptor pyrin-domain containing protein 3 ; FFAR3, free fatty acid receptor 3 ; GPR109A, G-protein-coupled receptor 109A; Kbhb, lysine $\beta$-hydroxybutyrylation. Figure produced as original artwork

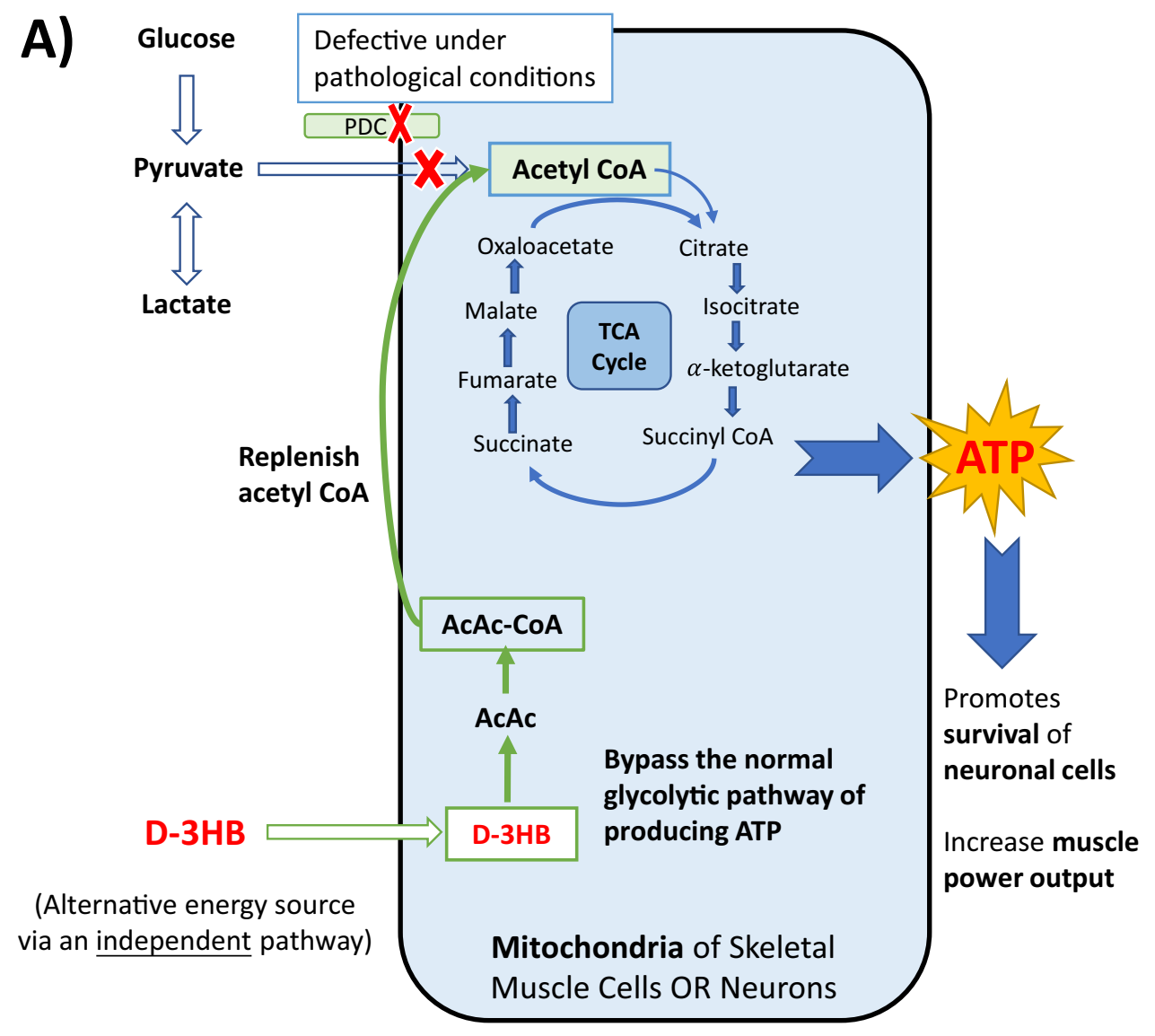

\section{B) Intracellular Actions of D-3HB at the Molecular Level}

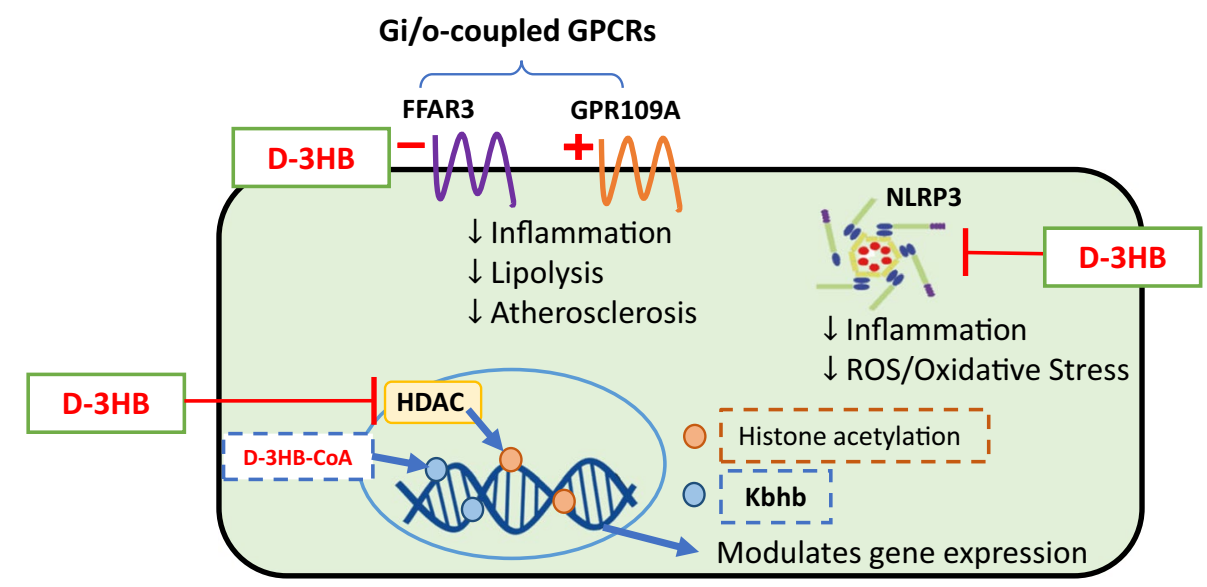

supplementations as a potential strategy to induce nutritional ketosis and enhance endurance exercise has already been thoroughly reviewed (Margolis and O'Fallon 2019; Shaw et al. 2020). Although some conflicting studies show how ingestion of $\mathrm{D}-3 \mathrm{HB}$ precursors failed to benefit long-term endurance exercise (Poffé et al. 2020), other evidences still show positive effects in terms of improving physical performance especially in well-trained athletes and using rodent models (Cox et al. 2016; Murray et al. 2016). Moreover, ketone supplements are capable of optimizing body composition by reducing body lipids without affecting lean body mass (Vargas et al. 2018), thus implies that ketone utilization can prevent excessive muscle breakdown during weight loss. This is crucial for many weight-sensitive sports such as weight-lifting. In fact, a recent review has specifically focused on how D-3HB promoted muscle recovery following exercise (Mansor and Woo 2021). 
Fig. 4 Summary of the recently explored applications of D-3HB within the human body. The various cellular actions of $\mathrm{D}$ $3 \mathrm{HB}$ have been divided up into groups with implications for treating different metabolic and age-related diseases. Abbreviations in figure: HDACs, histone deacetylases; NLRP3, nod-like receptor pyrindomain containing protein 3; mTORC, mechanistic target of rapamycin complex; Kbhb, lysine $\beta$-hydroxybutyrylation; CKD, chronic kidney disease; ADPKD, autosomal dominant polycystic kidney disease; PTSD, post-traumatic stress disorder; HT, hypertension; ATH, atherosclerosis; MADD, multi acyl-CoA dehydrogenase deficiency. Figure produced as original artwork

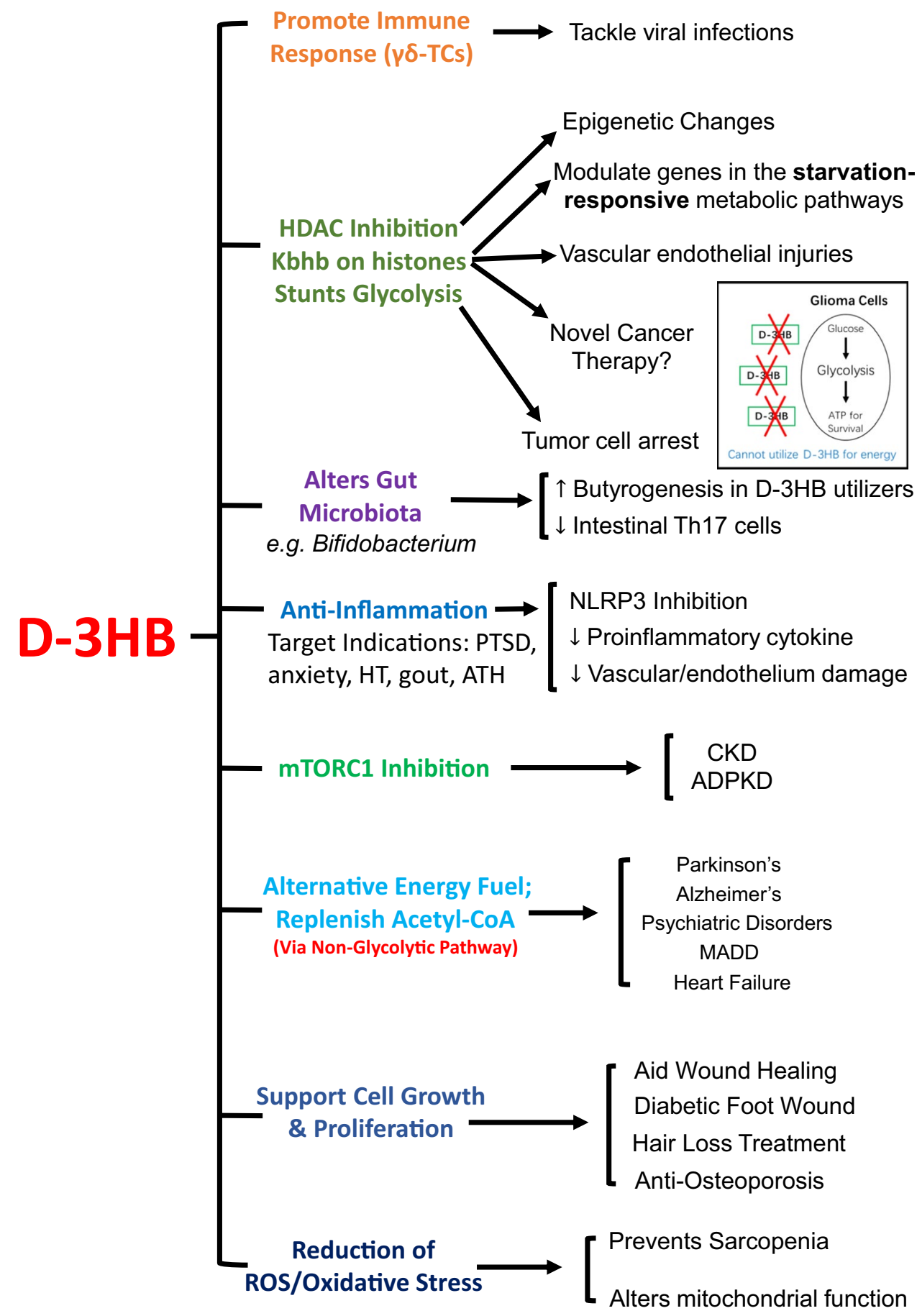

Specifically, D-3HB modulates skeletal muscle cell function via a ketone-induced muscle protein sparing effect and increases mitochondrial fusion, which enhances cellular viability and improves mitochondrial function (Parker et al. 2018). Similar muscle-sparing effect was demonstrated through in vitro incubation with $2-4 \mathrm{mM}$ of $\mathrm{D}-3 \mathrm{HB}$ salt in the epitrochlearis muscle $2 \mathrm{~h}$ following exercise (Takahashi et al. 2019). Furthermore, the enhancement in post-exercise recovery has also been proven in athletes who consumed the KME following strenuous exercise whereby more than $50 \%$ increase in muscle glycogen content was observed compared to control (Holdsworth et al. 2017). Such effect may be caused by an increase in leucine-mediated activation of the mechanistic target of rapamycin complex 1 (mTORC1) which increased the rate of protein synthesis (Vandoorne et al. 2017). The overall outcome is a preservation of skeletal muscle mass which 
would be highly beneficial for maintaining performance in resistance training and weight-sensitive sports.

\section{D-3HB and cardiometabolic health}

Obesity has been one of the biggest metabolic complications in today's society affecting millions of individuals worldwide. It is also linked to other cardiovascular diseases such as atherosclerosis which leads to life-threatening situations (Kachur et al. 2017). Lifestyle alteration is a key strategy used to tackle obesity and long-term KDs or verylow-energy diets have already been explored as a promising treatment strategy (Gow et al. 2021; Kumar et al. 2021).

First of all, D-3HB was shown to be able to improve the blood lipid profile in obese adults by a reduction in lowdensity lipoprotein (LDL) cholesterol, increase in highdensity lipoprotein (HDL) cholesterol, smaller adipocyte cell volume, and inhibition of lipolysis via a G-protein-coupled receptor (GPCR) which reduced subsequent release of serum lipolytic products (Caminhotto et al. 2017). At the cellular level, D-3HB markedly increased mitochondrial uncoupling in brown adipose tissue (BAT) which increased mitochondrial respiration and thermogenesis, thereby results in increased resting energy expenditure (REE) in the obese (Deemer et al. 2020; Walton et al. 2020). More recently, studies revealed that the anti-inflammatory actions of D$3 \mathrm{HB}$ on the NOD-like receptor pyrin-domain containing 3 (NLRP3) inflammasome in obese adults can also prevent obesity and associated cardiometabolic complications such as atherosclerosis (Neudorf et al. 2020; Zhang et al. 2021). The latter study revealed a specific pathway by which D$3 \mathrm{HB}$ acts to alleviate atherosclerosis via activation of the GPCR109A, which is known to be key endogenous receptors of D-3HB (Zhang et al. 2021).

As a central regulator of cardiometabolic health, D-3HB acts as an alternative fuel particularly to the heart and the kidneys (Hattori 2021; Yurista et al. 2021a). Interestingly, D-3HB functions in different ways within the two organs due to a high or low abundance of the succinyl-CoA:3-ketoacid CoA transferase (SCOT) present in the heart and kidneys, respectively (Hattori 2021). It has been recently elucidated that the failing heart utilizes D-3HB more efficiently than the non-failing heart (Murashige et al. 2020). Hence, infusion of D-3HB to chronic heart failure (HF) patients (Monzo et al. 2021) and animal HF models (Yurista et al. 2021b) significantly increased cardiac output (CO) and such increase occurred in a dose-dependent way (Nielsen et al. 2019). Meanwhile, D-3HB was also demonstrated to rescue HF by reducing excessive mitochondrial hyperacetylation through inhibition of NLRP3 inflammasome (Deng et al. 2021).

Within the kidneys, the renoprotective roles of D-3HB are mostly mediated through endogenous inhibition of histone deacetylases (HDAC) and NLRP3 which leads to subsequent inhibition of mTORC1, inflammation, oxidative stress, and tissue fibrosis (Hattori 2021). Moderately elevated ketone bodies by sodium-glucose cotransporter 2 (SGLT2) inhibitors have been shown to potentiate the renoprotective effects of the drug in chronic kidney disease via inhibition of mTORC1 hyperactivation (Tomita et al. 2020). In addition, D-3HB also alleviated secondary metabolic complications such as cognitive impairments in DM patients (Jensen et al. 2020a).

\section{D-3HB and brain health}

Ketone bodies have long been utilized as a strategy for treating refractory epilepsy in children and infants (Thompson et al. 2017; Zarnowska 2020). It was recently demonstrated that D-3HB elicited its anti-epileptic effect through activation of $K_{\mathrm{ATP}}$ channels and $\mathrm{GABA}_{\mathrm{B}}$ signaling, which led to reduced neuronal firing ( $\mathrm{Li}$ et al. 2017). Recent studies have revealed novel signaling pathways by which D-3HB may be involved (Wang et al. 2021), as well as its potential for treating other forms of epilepsy (Brunner et al. 2021).

Nowadays, age-related neurodegeneration has become a highly prominent issue around the world, which was usually characterized by glucose hypometabolism in the brain (Jensen et al. 2020b). Novel strategies using ketone bodies have emerged which offers neuroprotection and alleviates pathologies in many neurological and psychiatric disorders (Kovács et al. 2019; Norwitz et al. 2020). Importantly, it was shown that D-3HB competes with glucose for energy metabolism in the brain (Suissa et al. 2021). Moreover, the utilization of D-3HB stabilized brain networks in an aging model while glucose destabilized brain network stability (Mujica-Parodi et al. 2020).

To date, a number of studies have investigated the pathways by which D-3HB acts to ameliorate Alzheimer's and Parkinson's Disease in rodent models (Kashiwaya et al. 2000; Wu et al. 2020b). In fact, in one clinical report of a patient with sporadic ALZ following treatment with KME, the patient demonstrated remarkable improvements in mood, self-caring ability, cognitive, and physical performance (Newport et al. 2015). D-3HB was recently proven to mitigate both positive and negative schizophrenia (SCZ)-like symptoms in drug-induced SCZ rats by overcoming the energy deficit caused by glucose hypometabolism in the cerebral brain (Kraeuter et al. 2020). Furthermore, endogenous NLRP3 inhibition by D-3HB alleviated stress-induced anxiety and post-traumatic stress disorder (PTSD) (Yamanashi et al. 2017, 2020). D-3HB also promoted the effect of a subtherapeutic dose of an anti-depressant drug, which led to suppression of chronic unpredictable stress-induced increase in immobility time and reduction in body weight in rat studies (Pan et al. 2020). 


\section{D-3HB and implications in osteoporosis, diabetic foot, and hair loss}

D-3HB may be beneficial in the treatment and prevention of osteoporosis due to its ability to promote the growth of bone osteoblast cells (Cao et al. 2014). Moreover, different research groups have demonstrated that $\mathrm{D}-3 \mathrm{HB}$ promotes the growth and proliferation of other cell types such as skin cells (Ji et al. 2008), neural cells (Xiao et al. 2007), and hair follicular cells (Han et al. 2007). Thus, D-3HB may exhibit a role in multiple conditions such as wound healing, cognition, and hair loss prevention respectively (Han et al. 2007; Zou et al. 2009; Gumel et al. 2015).

A recent investigation also forecasts how D-3HB may help to alleviate hair loss caused by excessive inflammation through its inhibitory effect on NLRP3 in macrophages which reduces subsequent release of proinflammatory cytokines (Goldberg et al. 2017). Surprisingly, D-3HB may be effective against genetically inherited hair loss conditions although the specific mechanisms are unknown (Della Marina et al. 2020). Other studies also implicate that downstream mechanisms of D-3HB such as reducing reactive oxygen species (ROS) and inflammation can aid the wound-healing process (Kesl 2016) hence may be useful in the treatment of diabetic foot (Kato et al. 2014). In addition, D-3HB was also demonstrated to induce differentiation of intestinal cells and functions in the maintenance of intestinal homeostasis (Cheng et al. 2019).

\section{D-3HB and implications in fighting viral infections}

A very recent investigation suggested that $\mathrm{D}-3 \mathrm{HB}$ exhibits anti-viral properties which can target respiratory viral infections such as the Influenza A virus or the severe acute respiratory syndrome (SARS)-CoV-2 virus via different intracellular mechanisms (Stubbs et al. 2020). Thus, researchers hypothesize that D-3HB may also help alleviate the COVID19 pandemic by promoting the immune response or mitigating critical risk factors that make individuals susceptible to COVID-19 such as obesity, T2D, and CVDs (Paoli et al. 2020).

\section{D-3HB and implications in cancer}

Emerging research suggests that D-3HB may exhibit an important role against cancer by either starving tumor cells which normally depend on glucose metabolism for survival (Maurer et al. 2011; Vallejo et al. 2020; Barrea et al. 2020). According to recent literature, ketogenic metabolic therapy had already been proven effective for use in glioblastomas (Winter et al. 2017) and neuroblastomas (He et al. 2020). Specifically, one study demonstrated that the KD inhibited proliferation and stemness of glioma cells and glioma-like stem cells by altering energy metabolism which resulted in increased reactive oxygen species (ROS) production and increased apoptosis of tumor cells (Ji et al. 2019). In addition, D-3HB may also enhance the anti-cancer effects of existing drugs and chemotherapies (Feng et al. 2019; Wang et al. 2020) while other investigations have proposed the possibility of D-3HB in alleviating some types of advanced cancers (Iyikesici 2020; Hagihara et al. 2020). More recently, Tengesdal et al. have identified a novel pathway for treating melanomas by targeting tumor-derived NLRP3 activation which limited expansion of myeloid-derived suppressor cells (MDSCs) via inhibition of interleukin-1 $\beta$ (IL$1 \beta)$ production, leading to reduced tumor growth through enhanced anti-tumor immunity (Tengesdal et al. 2021). The group concluded that a combination of NLRP3 inhibition and anti-PD-1 therapy could potentiate the efficacy of the monotherapy in treating melanomas, and that NLRP3, which is a key cellular target of D-3HB (Shang et al. 2018), may become a novel therapeutic target for human melanomas.

\section{D-3HB signaling in the regulation of metabolism}

It was only until recent years when D-3HB was identified as an epigenetic modifier due to its function as a HDAC inhibitor which promotes protein acetylation, resulting in metabolic reprogramming and changes in expression of downstream transcription factors or metabolic enzymes that are associated with cancers or other metabolic diseases (Sun et al. 2021). In particular, it was recently discovered that D-3HB induces a novel post-translational modification known as lysine $\beta$-hydroxybutyrylation (Kbhb) (Xie et al. 2016). Consequently, Kbhb caused an increase in histone acetylation which altered downstream gene expressions. One particular study has demonstrated that Kbhb on the lysine residues of histone 3 (H3K9) activated gene expressions that led to upregulation of the vascular endothelial growth factor (VEGF), which protected against aortic endothelial injury in diabetic rats (Wu et al. 2020a). It was also predicted that hyperacetylation on $\mathrm{H} 3 \mathrm{~K} 9$ and $\mathrm{H} 3 \mathrm{~K} 14$ might contribute to reduced incidence of cancer (Dąbek et al. 2020). Indeed, the relevant epigenetic roles played by D-3HB in cancer remains of question and controversial (Liu et al. 2019); therefore, further mechanistic research are still needed in order to develop D-3HB into novel anti-cancer therapies for the future.

\section{Conclusion and future perspectives}

In summary, D-3HB is a small molecule that plays multiple roles in the human body in terms of regulating physical and metabolic health (Fig. 4; Table 2). Indeed, the positive effects of D-3HB span from nutrition and exercise to the prevention and treatment of metabolic and age-related 
diseases (Tables 1 \& 2). So far, a large number of studies have focused on neurological and cardiovascular benefits of D-3HB in humans and animal models (Table 2). In recent years, the use of exogenous ketone supplements has increased in popularity which induced rapid ketosis without the need to comply to the KD. Ingestion of D-3HB could effectively optimize the body composition of athletes, leading to enhanced exercise performance (Table 1). However, ingestion of ketone salts and esters was associated with unwanted GI side effects or requires further degradation before releasing D-3HB for absorption.

To our knowledge, there has been no direct investigation based on supplementing the free acid form of D-3HB as a beverage drink to humans or animals yet due to difficulties in obtaining the free acid form in large amounts. Hence, the recently patented technology which utilizes a biosynthetic process to produce $\mathrm{D}-3 \mathrm{HB}$ acid on a kilogram scale is considered a first-time success within this field. Due to its novelty, we propose that further in vitro and in vivo pharmacokinetics, dose-response relationships, and safety and tolerability studies using the acid can be investigated. At last, we hope that the availability of such free D-3HB acid on a large scale may attract and aid scientists and researchers worldwide in developing novel treatments which will benefit the overall metabolic health of humans and potentially extend human life expectancy.

Author contribution Guo-Qiang Chen supervised this research. ZL, JL, LS, SW, LX, and HW contributed to research and data collection and analysis. AY wrote the manuscript. ZL and G-QC edited the manuscript. All authors read and approved the manuscript.

Funding This research was financially supported by a grant from Chunfeng Foundation (2020Z99CFG002) of Tsinghua University, and Key Project grants from the Ministry of Science and Technology of China (Grant No. 2018YFA0900200), National Natural Science Foundation of China (Grant No. 31961133019; No. 21761132013; No. 31870859), and Center of Life Sciences of Tsinghua-Peking University. This project is also funded by the National Natural Science Foundation of China (grant numbers 31961133017, 31961133018, 31961133019). These grants are part of MIX-UP, a joint NSFC and EU H2020 collaboration. In Europe, MIX-UP has received funding from the European Union's Horizon 2020 research and innovation program under grant agreement No 870294.

\section{References}

Anjum A, Zuber M, Zia KM, Noreen A, Anjum MN, Tabasum S (2016) Microbial production of polyhydroxyalkanoates (PHAs) and its copolymers: a review of recent advancements. Int J Biol Macromol 89:161-174. https://doi.org/10.1016/j.ijbiomac.2016.04.069

Balasse EO, Féry F (1989) Ketone body production and disposal: effects of fasting, diabetes, and exercise. Diabetes Metab Rev 5:247-270. https://doi.org/10.1002/dmr.5610050304

Barrea L, Caprio M, Tuccinardi D, Moriconi E, Di Renzo L, Muscogiuri G, Colao A, Savastano S (2020) Could ketogenic diet "starve" cancer? Emerging evidence. Crit Rev Food Sci Nutr 1-22. https://doi.org/10.1080/10408398.2020.1847030

Bleeker JC, Visser G, Clarke K, Ferdinandusse S, de Haan FH, Houtkooper RH, IJlst L, Kok IL, Langeveld M, van der Pol WL, de Sain-van der Velden MGM, Sibeijn-Kuiper A, Takken T, Wanders RJA, van Weeghel M, Wijburg FA, van der Woude LH, Wüst RCI, Cox PJ, Jeneson JAL (2020) Nutritional ketosis improves exercise metabolism in patients with very longchain acyl-CoA dehydrogenase deficiency. J Inherit Metab Dis 43:787-799. https://doi.org/10.1002/jimd.12217

Brunner B, Rauch E, Ari C, D’agostino DP, Kovács Z (2021) Enhancement of ketone supplements-evoked effect on absence epileptic activity by co-administration of uridine in Wistar Albino Glaxo Rijswijk rats. Nutrients 13:1-14. https://doi.org/ $10.3390 /$ nu 13010234

Cahill GF (2006) Fuel metabolism in starvation. Annu Rev Nutr 26:1-22. https://doi.org/10.1146/annurev.nutr.26.061505. 111258

Caminhotto RDO, Komino ACM, de Fatima SF, Andreotti S, Sertié RAL, Boltes Reis G, Lima FB (2017) Oral $\beta$-hydroxybutyrate increases ketonemia, decreases visceral adipocyte volume and improves serum lipid profile in Wistar rats. Nutr Metab (lond) 14:31-40. https://doi.org/10.1186/s12986-017-0184-4

Cao Q, Zhang J, Liu H, Wu Q, Chen J, Chen GQ (2014) The mechanism of anti-osteoporosis effects of 3-hydroxybutyrate and derivatives under simulated microgravity. Biomaterials 35:8273-8283. https://doi.org/10.1016/j.biomaterials.2014.06.020

Chen G-Q, Xi J, Wu Q, Zhang G (2002) A biological method of producing (R) - $\beta$-hydroxybutyric acid using recombinant E.Coli. [Patent No.CN1357629A]

Cheng CW, Biton M, Haber AL, Gunduz N, Eng G, Gaynor LT, Tripathi S, Calibasi-Kocal G, Rickelt S, Butty VL, Moreno-Serrano M, Iqbal AM, Bauer-Rowe KE, Imada S, Ulutas MS, Mylonas C, Whary MT, Levine SS, Basbinar Y, Hynes RO, Mino-Kenudson M, Deshpande V, Boyer LA, Fox JG, Terranova C, Rai K, Piwnica-Worms H, Mihaylova MM, Regev A, Yilmaz ÖH (2019) Ketone body signaling mediates intestinal stem cell homeostasis and adaptation to diet. Cell 178:1115-1131.e15. https://doi.org/ 10.1016/j.cell.2019.07.048

Cox PJ, Kirk T, Ashmore T, Willerton K, Evans R, Smith A, Murray AJ, Stubbs B, West J, McLure SW, King MT, Dodd MS, Holloway C, Neubauer S, Drawer S, Veech RL, Griffin JL, Clarke K (2016) Nutritional ketosis alters fuel preference and thereby endurance performance in athletes. Cell Metab 24:256-268. https://doi.org/10.1016/j.cmet.2016.07.010

Cuenoud B, Hartweg M, Godin JP, Croteau E, Maltais M, Castellano CA, Carpentier AC, Cunnane SC (2020) Metabolism of exogenous D-beta-hydroxybutyrate, an energy substrate avidly consumed by the heart and kidney. Front Nutr 7:1-9. https://doi.org/ 10.3389/fnut.2020.00013

Dąbek A, Wojtala M, Pirola L, Balcerczyk A (2020) Modulation of cellular biochemistry, epigenetics and metabolomics by ketone bodies. implications of the ketogenic diet in the physiology of the organism and pathological states. Nutrients 12:788-802. https:// doi.org/10.3390/nu12030788

Davis RAH, Deemer SE, Bergeron JM, Little JT, Warren JL, Fisher G, Smith DL, Fontaine KR, Dickinson SL, Allison DB, Plaisance EP (2019) Dietary R, S-1,3-butanediol diacetoacetate reduces body weight and adiposity in obese mice fed a high-fat diet. FASEB J 33:2409-2421. https://doi.org/10.1096/fj.20180 0821RR

Deemer SE, Davis RAH, Roberts BM, Smith DL, Koutnik AP, Poff AM, D'Agostino DP, Plaisance EP (2020) Exogenous dietary ketone ester decreases body weight and adiposity in mice housed at thermoneutrality. Obesity 28:1447-1455. https://doi.org/10. 1002/oby. 22855 
Della Marina A, Leiendecker B, Roesch S, Wortmann SB (2020) Ketogenic diet for treating alopecia in bcs11-related mitochondrial disease Bjornstad syndrome. JIMD Rep 53:10-11. https:// doi.org/10.1002/jmd2.12109

Deng Y, Xie M, Li Q, Xu X, Ou W, Zhang Y, Xiao H, Yu H, Zheng Y, Liang Y, Jiang C, Chen G, Du D, Zheng W, Wang S, Gong M, Chen Y, Tian R, Li T (2021) Targeting mitochondria-inflammation circuit by $\beta$-hydroxybutyrate mitigates HFpEF. Circ Res 128:232-245. https://doi.org/10.1161/CIRCRESAHA.120. 317933

Feng S, Wang H, Wang Y, Sun R, Xie Y, Zhou Z, Wang H, Aa J, Zhou F, Wang G (2019) Apatinib induces 3-hydroxybutyric acid production in the liver of mice by peroxisome proliferator-activated receptor $\alpha$ activation to aid its antitumor effect. Cancer Sci 110:3328-3339. https://doi.org/10.1111/cas.14168

Fischer T, Och U, Klawon I, Och T, Grüneberg M, Fobker M, Bordewick-Dell U, Marquardt T (2018) Effect of a sodium and calcium DL- $\beta$-hydroxybutyrate salt in healthy adults. J Nutr Metab 2018:1-8. https://doi.org/10.1155/2018/9812806

Fischer T, Elpers C, Och U, Fobker M, Marquardt T (2019a) Ketone body therapy with $\mathrm{D} / \mathrm{L}-\beta$-hydroxybutyric acid solution in severe MADD. Mol Genet Metab Reports 20:100491-100496. https:// doi.org/10.1016/j.ymgmr.2019.100491

Fischer T, Och U, Marquardt T (2019b) Long-term ketone body therapy of severe multiple acyl-CoA dehydrogenase deficiency: a case report. Nutrition 60:122-128. https://doi.org/10.1016/j.nut.2018. 10.014

Goldberg EL, Asher JL, Molony RD, Shaw AC, Zeiss CJ, Wang C, Morozova-Roche LA, Herzog RI, Iwasaki A, Dixit VD (2017) $\beta$-hydroxybutyrate deactivates neutrophil nlrp3 inflammasome to relieve gout flares. Cell Rep 18:2077-2087. https://doi.org/ 10.1016/j.celrep.2017.02.004

Gow ML, Pham-Short A, Jebeile H, Varley BJ, Craig ME (2021) Current perspectives on the role of very-low-energy diets in the treatment of obesity and type 2 diabetes in youth. diabetes. Metab Syndr Obes Targets Ther 14:215-225. https://doi.org/10.2147/ DMSO.S238419

Gumel AM, Razaif-Mazinah MRM, Anis SNS, Annuar MSM (2015) Poly (3-hydroxyalkanoates)-co-(6-hydroxyhexanoate) hydrogel promotes angiogenesis and collagen deposition during cutaneous wound healing in rats. Biomed Mater 10:045001. https://doi.org/ 10.1088/1748-6041/10/4/045001

Haas T, Hecker A, Potter M, Bulter T (2018) A method of synthesizing 3-hydroxybutyric acid. [Patent No.WO2017/016902]

Habieb ME, Mohamed MA, El Gamal DM, Hawas AM, Mohamed TM (2021) Anti-aging effect of DL- $\beta$-hydroxybutyrate against hepatic cellular senescence induced by D-galactose or $\gamma$-irradiation via autophagic flux stimulation in male rats. Arch Gerontol Geriatr 92:e104288. https://doi.org/10.1016/j.archger. 2020.104288

Hagihara K, Kajimoto K, Osaga S, Nagai N, Shimosegawa E, Nakata H, Saito H, Nakano M, Takeuchi M, Kanki H, Kagitani-Shimono K, Kijima T (2020) Promising effect of a new ketogenic diet regimen in patients with advanced cancer. Nutrients 12:1473-1485. https://doi.org/10.3390/nu12051473

Han I, Shim KJ, Kim JY, Im SU, Sung YK, Kim M, Kang IK, Kim JC (2007) Effect of poly(3-hydroxybutyrate-co-3-hydroxyvalerate) nanofiber matrices cocultured with hair follicular epithelial and dermal cells for biological wound dressing. Artif Organs 31:801808. https://doi.org/10.1111/j.1525-1594.2007.00466.x

Han Y-M, Ramprasath T, Zou M-H (2020) $\beta$-hydroxybutyrate and its metabolic effects on age-associated pathology. Exp Mol Med 52:548-555. https://doi.org/10.1038/s12276-020-0415-Z

Hattori Y (2021) Beneficial effects on kidney during treatment with sodium-glucose cotransporter 2 inhibitors: proposed role of ketone utilization. Heart Fail Rev. https://doi.org/10.1007/ s10741-020-10065-7

He J, Lü L, Peng J, Li C, Kong X, Zhang J, Peng L (2020) Inhibitory effect of ketogenic diet on neuroblastoma in BALB/c-nu mouse models. Nan Fang Yi Ke Da Xue Xue Bao 40:1155-1164. https:// doi.org/10.12122/j.issn.1673-4254.2020.08.13

Holdsworth DA, Cox PJ, Kirk T, Stradling H, Impey SG, Clarke K (2017) A ketone ester drink increases postexercise muscle glycogen synthesis in humans. Med Sci Sport Exerc 49:1789-1795. https://doi.org/10.1249/MSS.0000000000001292

Horwich TB, Fonarow GC (2011) Glucose, obesity, metabolic syndrome, and diabetes: relevance to incidence of heart failure. J Am Coll Cardiol 55:283-293. https://doi.org/10.1016/j.jacc. 2009.07.029

Iyikesici MS (2020) Long-term survival outcomes of metabolically supported chemotherapy with gemcitabine-based or FOLFIRINOX regimen combined with ketogenic diet, hyperthermia, and hyperbaric oxygen therapy in metastatic pancreatic cancer. Complement Med Res 27:31-39. https://doi.org/10.1159/00050 2135

Jensen NJ, Nilsson M, Ingerslev JS, Olsen DA, Fenger M, Svart M, Møller N, Zander M, Miskowiak KW, Rungby J (2020a) Effects of $\beta$-hydroxybutyrate on cognition in patients with type 2 diabetes. Eur J Endocrinol 182:233-242. https://doi.org/10.1530/ EJE-19-0710

Jensen NJ, Wodschow HZ, Nilsson M, Rungby J (2020b) Effects of ketone bodies on brain metabolism and function in neurodegenerative diseases. Int J Mol Sci 21:1-17. https://doi.org/10.3390/ ijms 21228767

Ji Y, Li X-T, Chen G-Q (2008) Interactions between a poly(3-hydroxybutyrate-co-3-hydroxyvalerate-co-3-hydroxyhexanoate) terpolyester and human keratinocytes. Biomaterials 29:3807-3814. https://doi.org/10.1016/j.biomaterials.2008.06.008

Ji C, Hu Y, Cheng G, Liang L, Gao B, Ren Y, Liu J, Cao X, Zheng M, Li S, Wan F, Han H, Fei Z (2019) A ketogenic diet attenuates proliferation and stemness of glioma stem-like cells by altering metabolism resulting in increased ROS production. Int J Oncol 56:606-617. https://doi.org/10.3892/ijo.2019.4942

Kachur S, Lavie CJ, de Schutter A, Milani RV, Ventura HO (2017) Obesity and cardiovascular diseases. Minerva Med 108:212-228. https://doi.org/10.23736/s0026-4806.17.05022-4

Kackley ML, Short JA, Hyde PN, LaFountain RA, Buga A, Miller VJ, Dickerson RM, Sapper TN, Barnhart EC, Krishnan D, McElroy CA, Maresh CM, Kraemer WJ, Volek JS (2020) A pre-workout supplement of ketone salts, caffeine, and amino acids improves high-intensity exercise performance in keto-naïve and ketoadapted individuals. J Am Coll Nutr 39:290-300. https://doi. org/10.1080/07315724.2020.1752846

Kang J, Ratamess NA, Faigenbaum AD, Bush JA (2020) Ergogenic properties of ketogenic diets in normal-weight individuals: a systematic review. J Am Coll Nutr 39:665-675. https://doi.org/ 10.1080/07315724.2020.1725686

Kashiwaya Y, Takeshima T, Mori N, Nakashima K, Clarke K, Veech RL (2000) D-beta -Hydroxybutyrate protects neurons in models of Alzheimer's and Parkinson's disease. Proc Natl Acad Sci 97:5440-5444. https://doi.org/10.1073/pnas.97.10.5440

Kato J, Kamiya H, Himeno T, Shibata T, Kondo M, Okawa T, Fujiya A, Fukami A, Uenishi E, Seino Y, Tsunekawa S, Hamada Y, Naruse K, Oiso Y, Nakamura J (2014) Mesenchymal stem cells ameliorate impaired wound healing through enhancing keratinocyte functions in diabetic foot ulcerations on the plantar skin of rats. J Diabetes Complications 28:588-595. https://doi.org/10. 1016/j.jdiacomp.2014.05.003

Kesl SL (2016) Metabolic therapy for age-dependent impaired wound healing. university of South Florida 
Kovács Z, D’Agostino DP, Diamond D, Kindy MS, Rogers C, Ari C (2019) Therapeutic potential of exogenous ketone supplement induced ketosis in the treatment of psychiatric disorders: review of current literature. Front Psychiatry 10:Article 363. https://doi. org/10.3389/fpsyt.2019.00363

Kraeuter A-K, Mashavave T, Suvarna A, van den Buuse M, Sarnyai Z (2020) Effects of beta-hydroxybutyrate administration on MK-801-induced schizophrenia-like behaviour in mice. Psychopharmacology 237:1397-1405. https://doi.org/10.1007/ s00213-020-05467-2

Kumar S, Behl T, Sachdeva M, Sehgal A, Kumari S, Kumar A, Kaur G, Yadav HN, Bungau S (2021) Implicating the effect of ketogenic diet as a preventive measure to obesity and diabetes mellitus. Life Sci 264:Article 118661. https://doi.org/10.1016/j.lfs.2020. 118661

Lee TH, Yau S (2020) From obesity to hippocampal neurodegeneration: pathogenesis and non-pharmacological interventions. Int J Mol Sci 22:201-234. https://doi.org/10.3390/ijms22010201

Li J, O'Leary EI, Tanner GR (2017) The ketogenic diet metabolite beta-hydroxybutyrate $(\beta-\mathrm{HB})$ reduces incidence of seizure-like activity (SLA) in a $\mathrm{K}$ atp- and GABA b-dependent manner in a whole-animal Drosophila melanogaster model. Epilepsy Res 133:6-9. https://doi.org/10.1016/j.eplepsyres.2017.04.003

Liu K, Li F, Sun Q, Lin N, Han H, You K, Tian F, Mao Z, Li T, Tong T, Geng M, Zhao Y, Gu W, Zhao W (2019) p53 $\beta$-hydroxybutyrylation attenuates p53 activity. Cell Death Dis 10:243-256. https://doi.org/10.1038/s41419-019-1463-y

Lyu J, Wei S, Yu L (2021) A novel method for producing (R)3-hydroxybutyric acid. Chinese Patent Application [Patent No.CN112176003A

Mansor LS, Woo GH (2021) Ketones for post-exercise recovery: potential applications and mechanisms. Front Physiol 11:Article 613648. https://doi.org/10.3389/fphys.2020.613648

Margolis LM, O'Fallon KS (2019) Utility of ketone supplementation to enhance physical performance: a systematic review. Adv Nutr 11:412-419. https://doi.org/10.1093/advances/nmz104

Maurer GD, Brucker DP, Bähr O, Harter PN, Hattingen E, Walenta S, Mueller-Klieser W, Steinbach JP, Rieger J (2011) Differential utilization of ketone bodies by neurons and glioma cell lines: a rationale for ketogenic diet as experimental glioma therapy. BMC Cancer 11:315-332. https://doi.org/10.1186/1471-2407-11-315

Millet G (2019) Non - racemic beta - hydroxybutyrate compounds and compositions enriched with the s - enantiomer and methods of use. [Patent No.US10245243B1]

Møller N (2020) Ketone body, 3-hydroxybutyrate: minor metabolite - major medical manifestations. J Clin Endocrinol Metab 105:2884-2892. https://doi.org/10.1210/clinem/dgaa370

Monzo L, Sedlacek K, Hromanikova K, Tomanova L, Borlaug BA, Jabor A, Kautzner J, Melenovsky V (2021) Myocardial ketone body utilization in patients with heart failure: the impact of oral ketone ester. Metabolism 115:https://www.metabolismjournal. com/article/S0026-04. https://doi.org/10.1016/j.metabol.2020. 154452

Mujica-Parodi LR, Amgalan A, Sultan SF, Antal B, Sun X, Skiena S, Lithen A, Adra N, Ratai E-M, Weistuch C, Govindarajan ST, Strey HH, Dill KA, Stufflebeam SM, Veech RL, Clarke K (2020) Diet modulates brain network stability, a biomarker for brain aging, in young adults. Proc Natl Acad Sci 117:6170-6177. https://doi.org/10.1073/pnas.1913042117

Murashige D, Jang C, Neinast M, Edwards JJ, Cowan A, Hyman MC, Rabinowitz JD, Frankel DS, Arany Z (2020) Comprehensive quantification of fuel use by the failing and nonfailing human heart. Science (80-) 370:364-368. https://doi.org/10.1126/scien ce.abc 8861

Murray AJ, Knight NS, Cole MA, Cochlin LE, Carter E, Tchabanenko K, Pichulik T, Gulston MK, Atherton HJ, Schroeder
MA, Deacon RMJ, Kashiwaya Y, King MT, Pawlosky R, Rawlins JNP, Tyler DJ, Griffin JL, Robertson J, Veech RL, Clarke K (2016) Novel ketone diet enhances physical and cognitive performance. FASEB J 30:4021-4032. https://doi.org/10.1096/ fj.201600773R

Neudorf H, Myette-Côté É, Little PJ (2020) The impact of acute ingestion of a ketone monoester drink on LPS-stimulated NLRP3 activation in humans with obesity. Nutrients 12:854-867. https://doi. org/10.3390/nu12030854

Newman JC, Verdin E (2014) Ketone bodies as signaling metabolites. Trends Endocrinol Metab 25:42-52. https://doi.org/10.1016/j. tem.2013.09.002

Newport MT, VanItallie TB, Kashiwaya Y, King MT, Veech RL (2015) A new way to produce hyperketonemia: use of ketone ester in a case of Alzheimer's disease. Alzheimers Dement 11:99-103. https://doi.org/10.1016/j.jalz.2014.01.006

Nielsen R, Møller N, Gormsen LC, Tolbod LP, Hansson NH, Sorensen J, Harms HJ, Frøkiær J, Eiskjaer H, Jespersen NR, Mellemkjaer S, Lassen TR, Pryds K, Bøtker HE, Wiggers H (2019) Cardiovascular effects of treatment with the ketone body 3-hydroxybutyrate in chronic heart failure patients. Circulation 139:2129-2141. https://doi.org/10.1161/CIRCULATIONAHA.118.036459

Norwitz NG, Jaramillo JG, Clarke K, Soto A (2020) Ketotherapeutics for neurodegenerative diseases. In: International Review of Neurobiology. Academic Press Inc, pp 141-168

O’Malley T, Myette-Cote E, Durrer C, Little JP (2017) Nutritional ketone salts increase fat oxidation but impair high-intensity exercise performance in healthy adult males. Appl Physiol Nutr Metab 42:1031-1035. https://doi.org/10.1139/apnm-2016-0641

Pan S, Hu P, You Q, Chen J, Wu J, Zhang Y, Cai Z, Ye T, Xu X, Chen $\mathrm{Z}$, Tong L, Huang C, He H (2020) Evaluation of the antidepressive property of $\beta$-hydroxybutyrate in mice. Behav Pharmacol 31:322-332. https://doi.org/10.1097/FBP.0000000000000535

Paoli A, Gorini S, Caprio M (2020) The dark side of the spoon - glucose, ketones and COVID-19: a possible role for ketogenic diet? J Transl Med 18:441-450. https://doi.org/10.1186/ s12967-020-02600-9

Park J-S, Kim Y-J (2020) Anti-aging effect of the ketone metabolite $\beta$-hydroxybutyrate in drosophila intestinal stem cells. Int J Mol Sci 21:3497-3510. https://doi.org/10.3390/ijms21103497

Parker B, Walton C, Carr S, Andrus J, Cheung E, Duplisea M, Wilson E, Draney C, Lathen D, Kenner K, Thomson D, Tessem J, Bikman B (2018) $\beta$-hydroxybutyrate elicits favorable mitochondrial changes in skeletal muscle. Int J Mol Sci 19:2247-2259. https:// doi.org/10.3390/ijms19082247

Poff AM, Koutnik AP, Egan B (2020) Nutritional ketosis with ketogenic diets or exogenous ketones: features, convergence, and divergence. Curr Sports Med Rep 19:251-259. https://doi.org/ 10.1249/JSR.0000000000000732

Poffé C, Ramaekers M, Bogaerts S, Hespel P (2020) Exogenous ketosis impacts neither performance nor muscle glycogen breakdown in prolonged endurance exercise. J Appl Physiol 128:1643-1653. https://doi.org/10.1152/japplphysiol.00092.2020

Rich AJ (1990) Ketone bodies as substrates. Proc Nutr Soc 49:361373. https://doi.org/10.1079/pns19900042

Schroeder J, Hynes HH (2021) Exogenous ketone supplementation compositions,systems and methods. [Patent No.US17002691]

Shang S, Wang L, Zhang Y, Lu H, Lu X (2018) The beta-hydroxybutyrate suppresses the migration of glioma cells by inhibition of NLRP3 inflammasome. Cell Mol Neurobiol 38:1479-1489. https://doi.org/10.1007/s10571-018-0617-2

Shaw DM, Merien F, Braakhuis A, Maunder E, Dulson DK (2020) Exogenous ketone supplementation and keto-adaptation for endurance performance: disentangling the effects of two distinct metabolic states. Sport Med 50:641-656. https://doi.org/10.1007/ s40279-019-01246-y 
Strazzullo P, D’Elia L, Kandala N-B, Cappuccio FP (2009) Salt intake, stroke, and cardiovascular disease: meta-analysis of prospective studies. BMJ 339:b4567. https://doi.org/10.1136/bmj.b4567

Stubbs BJ, Cox PJ, Evans RD, Santer P, Miller JJ, Faull OK, MagorElliott S, Hiyama S, Stirling M, Clarke K (2017) On the metabolism of exogenous ketones in humans. Front Physiol 8:Article 848. https://doi.org/10.3389/fphys.2017.00848

Stubbs BJ, Koutnik AP, Goldberg EL, Upadhyay V, Turnbaugh PJ, Verdin E, Newman JC (2020) Investigating ketone bodies as immunometabolic countermeasures against respiratory viral infections. Med 1:43-65. https://doi.org/10.1016/j.medj.2020.06.008

Stubbs BJ, Blade T, Mills S, Thomas J, Yufei X, Nelson FR, Higley N, Nikiforov AI, Rhiner MO, Verdin E, Newman JC (2021) In vitro stability and in vivo pharmacokinetics of the novel ketogenic ester, bis hexanoyl (R)-1,3-butanediol. Food Chem Toxicol 147:111859. https://doi.org/10.1016/j.fct.2020.111859

Suissa L, Kotchetkov P, Guigonis JM, Doche E, Osman O, Pourcher $\mathrm{T}$, Lindenthal S (2021) Ingested ketone ester leads to a rapid rise of acetyl-coa and competes with glucose metabolism in the brain of non-fasted mice. Int J Mol Sci 22:1-17. https://doi.org/ 10.3390/ijms22020524

Sun L, Zhang H, Gao P (2021) Metabolic reprogramming and epigenetic modifications on the path to cancer. Protein Cell. https:// doi.org/10.1007/s13238-021-00846-7

Takahashi Y, Terada S, Banjo M, Seike K, Nakano S, Hatta H (2019) Effects of $\beta$-hydroxybutyrate treatment on glycogen repletion and its related signaling cascades in epitrochlearis muscle during 120 min of postexercise recovery. Appl Physiol Nutr Metab 44:1311-1319. https://doi.org/10.1139/apnm-2018-0860

Tan D, Xue Y-S, Aibaidula G, Chen G-Q (2011) Unsterile and continuous production of polyhydroxybutyrate by Halomonas TD01. Bioresour Technol 102:8130-8136. https://doi.org/10.1016/j. biortech.2011.05.068

Tengesdal IW, Menon DR, Osborne DG, Neff CP, Powers NE, Gamboni F, Mauro AG, D'Alessandro A, Stefanoni D, Henen MA, Mills TS, De Graaf DM, Azam T, Vogeli B, Palmer BE, Pietras EM, DeGregori J, Tan A-C, Joosten LAB, Fujita M, Dinarello CA, Marchetti C (2021) Targeting tumor-derived NLRP3 reduces melanoma progression by limiting MDSCs expansion. Proc Natl Acad Sci 118:e2000915118. https://doi.org/10.1073/pnas.20009 15118

Thompson L, Fecske E, Salim M, Hall A (2017) Use of the ketogenic diet in the neonatal intensive care unit-safety and tolerability. Epilepsia 58:e36-e39. https://doi.org/10.1111/epi.13650

Tomita I, Kume S, Sugahara S, Osawa N, Yamahara K, Yasuda-Yamahara M, Takeda N, Chin-Kanasaki M, Kaneko T, Mayoux E, Mark M, Yanagita M, Ogita H, Araki S, Maegawa H (2020) SGLT2 inhibition mediates protection from diabetic kidney disease by promoting ketone body-induced mTORC1 inhibition. Cell Metab 32:404-419.e6. https://doi.org/10.1016/j.cmet.2020. 06.020

USA FDA (2015) GRAS Notices GRN No.515 D-beta-hydroxybutyrate ester. https://www.cfsanappsexternal.fda.gov/scripts/fdcc/index. $\mathrm{cfm}$ ?set=GRASNotices\&id=515. Accessed 4 Mar 2021

Vallejo FA, Shah SS, de Cordoba N, Walters WM, Prince J, Khatib Z, Komotar RJ, Vanni S, Graham RM (2020) The contribution of ketone bodies to glycolytic inhibition for the treatment of adult and pediatric glioblastoma. J Neurooncol 147:317-326. https:// doi.org/10.1007/s11060-020-03431-w

Vandoorne T, De Smet S, Ramaekers M, Van Thienen R, De Bock K, Clarke K, Hespel P (2017) Intake of a ketone ester drink during recovery from exercise promotes mTORC1 signaling but not glycogen resynthesis in human muscle. Front Physiol 8:Article 310. https://doi.org/10.3389/fphys.2017.00310

Vargas S, Romance R, Petro JL, Bonilla DA, Galancho I, Espinar S, Kreider RB, Benítez-Porres J (2018) Efficacy of ketogenic diet on body composition during resistance training in trained men: a randomized controlled trial. J Int Soc Sports Nutr 15:31-40. https://doi.org/10.1186/s12970-018-0236-9

Veech L, Chance B, Yoshihiro R (2001) Ketone bodies, potential therapeutic uses. IUBMB Life (international Union Biochem Mol Biol Life) 51:241-247. https://doi.org/10.1080/152165401753311780

Waldman HS, McAllister MJ (2020) Exogenous ketones as therapeutic signaling molecules in high-stress occupations: implications for mitigating oxidative stress and mitochondrial dysfunction in future research. Nutr Metab Insights 13:1-7. https://doi.org/10. 1177/1178638820979029

Wallace MA, Aguirre NW, Marcotte GR, Marshall AG, Baehr LM, Hughes DC, Hamilton KL, Roberts MN, Lopez-Dominguez JA, Miller BF, Ramsey JJ, Baar K (2021) The ketogenic diet preserves skeletal muscle with aging in mice. Aging Cell 20:e13322. https://doi.org/10.1111/acel.13322

Walton CM, Jacobsen SM, Dallon BW, Saito ER, Bennett SLH, Davidson LE, Thomson DM, Hyldahl RD, Bikman BT (2020) Ketones elicit distinct alterations in adipose mitochondrial bioenergetics. Int J Mol Sci 21:1-14. https://doi.org/10.3390/ijms21176255

Wang Y, Jing M-X, Jiang L, Jia Y-F, Ying E, Cao H, Guo X-Y, Sun $\mathrm{T}$ (2020) Does a ketogenic diet as an adjuvant therapy for drug treatment enhance chemotherapy sensitivity and reduce target lesions in patients with locally recurrent or metastatic Her2-negative breast cancer? Study protocol for a randomized controlled trial. Trials 21:487-503. https://doi.org/10.1186/ s13063-020-04429-5

Wang J, Huang J, Li Y-Q, Yao S, Wu C-H, Wang Y, Gao F, Xu M-D, Huang G-B, Zhao C-Q, Wu J-H, Zhang Y-L, Jiao R, Deng Z-H, Jie W, Li H-B, Xuan A, Sun X-D (2021) Neuregulin 1/ ErbB4 signaling contributes to the anti-epileptic effects of the ketogenic diet. Cell Biosci 11:29-44. https://doi.org/10.1186/ s13578-021-00536-1

Wilkinson MJ, Manoogian ENC, Zadourian A, Lo H, Fakhouri S, Shoghi A, Wang X, Fleischer JG, Navlakha S, Panda S, Taub PR (2020) Ten-hour time-restricted eating reduces weight, blood pressure, and atherogenic lipids in patients with metabolic syndrome. Cell Metab 31:92-104.e5. https://doi.org/10.1016/j.cmet. 2019.11.004

Winter SF, Loebel F, Dietrich J (2017) Role of ketogenic metabolic therapy in malignant glioma: a systematic review. Crit Rev Oncol Hematol 112:41-58. https://doi.org/10.1016/j.critrevonc.2017. 02.016

Wu X, Miao D, Liu Z, Liu K, Zhang B, Li J, Li Y, Qi J (2020a) $\beta$-hydroxybutyrate antagonizes aortic endothelial injury by promoting generation of VEGF in diabetic rats. Tissue Cell 64:101345. https://doi.org/10.1016/j.tice.2020.101345

Wu Y, Gong Y, Luan Y, Li Y, Liu J, Yue Z, Yuan B, Sun J, Xie C, Li L, Zhen J, Jin X, Zheng Y, Wang X, Xie L, Wang W (2020b) BHBA treatment improves cognitive function by targeting pleiotropic mechanisms in transgenic mouse model of Alzheimer's disease. FASEB J 34:1412-1429. https://doi.org/10.1096/fj.201901984R

Xiao XQ, Zhao Y, Chen GQ (2007) The effect of 3-hydroxybutyrate and its derivatives on the growth of glial cells. Biomaterials 28:3608-3616. https://doi.org/10.1016/j.biomaterials.2007.04 046

Xie Z, Zhang D, Chung D, Tang Z, Huang H, Dai L, Qi S, Li J, Colak G, Chen Y, Xia C, Peng C, Ruan H, Kirkey M, Wang D, Jensen LM, Kwon OK, Lee S, Pletcher SD, Tan M, Lombard DB, White KP, Zhao H, Li J, Roeder RG, Yang X, Zhao Y (2016) Metabolic regulation of gene expression by histone lysine $\beta$-hydroxybutyrylation. Mol Cell 62:194-206. https://doi.org/10. 1016/j.molcel.2016.03.036

Yamanashi T, Iwata M, Kamiya N, Tsunetomi K, Kajitani N, Wada N, Iitsuka T, Yamauchi T, Miura A, Pu S, Shirayama Y, Watanabe K, Duman RS, Kaneko K (2017) Beta-hydroxybutyrate, 
an endogenic NLRP3 inflammasome inhibitor, attenuates stressinduced behavioral and inflammatory responses. Sci Rep 7:76777688. https://doi.org/10.1038/s41598-017-08055-1

Yamanashi T, Iwata M, Shibushita M, Tsunetomi K, Nagata M, Kajitani N, Miura A, Matsuo R, Nishiguchi T, Kato TA, Setoyama D, Shirayama Y, Watanabe K, Shinozaki G, Kaneko K (2020) Betahydroxybutyrate, an endogenous NLRP3 inflammasome inhibitor, attenuates anxiety-related behavior in a rodent post-traumatic stress disorder model. Sci Rep 10:21629-21640. https://doi.org/ 10.1038/s41598-020-78410-2

Yurista SR, Chong C-R, Badimon JJ, Kelly DP, de Boer RA, Westenbrink BD (2021a) Therapeutic potential of ketone bodies for patients with cardiovascular disease. J Am Coll Cardiol 77:16601669. https://doi.org/10.1016/j.jacc.2020.12.065

Yurista SR, Matsuura TR, Silljé HHW, Nijholt KT, McDaid KS, Shewale SV, Leone TC, Newman JC, Verdin E, van Veldhuisen DJ, de Boer RA, Kelly DP, Westenbrink BD (2021b) Ketone ester treatment improves cardiac function and reduces pathologic remodeling in preclinical models of heart failure. Circ Hear Fail
14:112-124. https://doi.org/10.1161/CIRCHEARTFAILURE. 120.007684

Zarnowska IM (2020) Therapeutic use of the ketogenic diet in refractory epilepsy: what we know and what still needs to be learned. Nutrients 12:2616. https://doi.org/10.3390/nu12092616

Zhang S, Li Z, Zhang Y, Chen J, Li Y, Wu F, Wang W, Cui ZJ, Chen G (2021) Ketone body 3-hydroxybutyrate ameliorates atherosclerosis via receptor Gpr109a-mediated calcium influx. Adv Sci 8:2003410. https://doi.org/10.1002/advs.202003410

Zou XH, Li HM, Wang S, Leski M, Yao YC, Di YX, Huang QJ, Chen GQ (2009) The effect of 3-hydroxybutyrate methyl ester on learning and memory in mice. Biomaterials 30:1532-1541. https://doi.org/10.1016/j.biomaterials.2008.12.012

Publisher's note Springer Nature remains neutral with regard to jurisdictional claims in published maps and institutional affiliations. 